\title{
Prawa ucznia: wiedza, opinie i doświadczenia gimnazjalistów. Badania własne
}

student's rights, entitlements, freedoms

\begin{abstract}
Dyrdół Małgorzata, Prawa ucznia: wiedza, opinie i doświadczenia gimnazjalistów. Badania własne [Student's Rights: Knowledge, Views and Experiences of Gymnasium Students. A Research Report]. Kultura - Społeczeństwo - Edukacja nr 1 (3) 2013, Poznań 2013, pp. 191-205, Adam Mickiewicz University Press. ISBN 978-83-232-2631-4. ISSN 2300-0422

This article reveals the findings of research on students's rights. The research was carried out twice: in 2006 and in 2012 among lower secondary school students. 223 participants from five schools have filled in the questionnaire form. This descriptive research show student's knowledge, opinion and experience on how their rights respected In their schools.
\end{abstract}

Przedmiotem badań przedstawionych w tym artykule są wiedza, poglądy i doświadczenia gimnazjalistów dotyczące ich uczniowskich praw. Temat ten podjęłam w przekonaniu, że jest on społecznie ważny, szkoła jest bowiem jedną z pierwszych i najważniejszych instytucji, z którymi dzieci mają kontakt. To w niej spędzają znaczną część dnia, wchodzą w różnorodne relacje interpersonalne, uczą się reguł życia społecznego oraz postępowania zgodnie z określonymi zasadami.

Szkoła przygotowuje młode pokolenia do życia w społeczeństwie, kształtując kompetencje, które będą niezbędne w ich dorosłym życiu, w tym także znajomość i zarazem umiejętność korzystania z przysługujących im praw. Od tego, jaka jest szkoła, zależy, jakie będzie społeczeństwo przyszłości, dlatego też dyskusja nad jej kształtem co jakiś czas jest podejmowana na nowo. Jednym z elementów tej dyskusji jest kwestia praw ucznia.

Podejmując problematykę praw ucznia, warto bliżej przyjrzeć się temu zagadnieniu na szczeblu szkół gimnazjalnych. Powszechnie uważa się bowiem, że właśnie w gimnazjach pojawiają się największe trudności związane z wprowadzaniem i realizacją uczniowskich praw. Uznałam zatem za interesujące i zarazem pożyteczne zbadanie wiedzy, poglądów i doświadczeń gimnazjalistów na ten temat. 
Samo prawo to system reguł zachowania, ogół norm ustanowionych lub uznawanych przez państwo, zabezpieczonych stosowaniem przymusu, regulujących organizację i zakres działania instytucji oraz postępowanie ludzi (Osuch, 2006: 462). W jego skład wchodzą uprawnienia i wolności. „Uprawnienia dotyczą roszczeń jednostki wysuwanych pod adresem innych ludzi, a prawa rozumiane jako wolności odnoszą się do własnych czynów podmiotu, które nie są nakazane ani zakazane przez prawo" (Partyka, 1996: 67).

Przedmiotem badań przedstawianych w tym artykule są zatem uprawnienia i wolności przysługujące dziecku, które ma status ucznia. Uprawnienia określają to, czego uczeń może oczekiwać, na przykład prawa do szacunku, a wolności to działania, które uczeń może podjąć, na przykład wypowiadać własne poglądy. Jak można zauważyć, prawa ucznia wywodzą się z praw dziecka, co zresztą często jest podkreślane w literaturze ${ }^{1}$.

Bogusław Śliwerski pod pojęciem praw ucznia rozumie:

ustanowione przez władze państwowe (m.in. oświatowe) lub podmioty niepubliczne prowadzące szkoły uprawnienia osób uczęszczających do szkół publicznych lub niepublicznych, które upoważniają ich do czynienia albo posiadania w tych instytucjach czegoś, co jest wobec nich słuszne, właściwe, „prawe”, regulując zarazem na tej podstawie relacje między nimi a sprawującymi wobec nich ową władzę osobami dorosłymi. (Śliwerski, 2012: 30)

Źródeł praw ucznia szukać należy w licznych dokumentach regulujących kwestię praw dziecka i zasady prawa oświatowego ${ }^{2}$; w większości szkół prawa te zapisane są w statucie szkoły i można je znaleźć w dzienniczku ucznia.

Wśród praw ucznia wyróżnić możemy: prawo do informacji, nauki, wypoczynku i czasu wolnego, zrzeszania się w organizacjach, szacunku i godnego traktowania, wolności myśli, sumienia i wyznania, wolności słowa, prywatności, bezpieczeństwa (w tym ochrony przed przemocą fizyczną i psychiczną) i sprawiedliwej oceny ${ }^{3}$.

1 Wykaz praw dziecka znajduje się m.in. w: A. Łopatka, Dziecko. Jego prawa człowieka, Polskie Wydawnictwo Prawnicze Iuris Sp. z o.o., Warszawa - Poznań 2000; E. Czyż, Prawa dziecka, Helsińska Fundacja Praw Człowieka, Warszawa 2002; S. Hart, C. P. Cohen, M. F. Ericson, M. Flekkoy, Prawa dzieci w edukacji, przeł. S. Pikiel, Gdańskie Wydawnictwo Psychologiczne, Gdańsk 2006; T. Smyczyński (red.), Konwencja o Prawach Dziecka. Analiza i wykładnia, Przedsiębiorstwo Wydawnicze „Ars boni et aequi”, Poznań 1999.

2 W Polsce nie obowiązuje osobny dokument wyliczający i opisujący prawa ucznia. Katalog praw i wolności osobistych, praw socjalnych, praw kulturalnych, prawa do nauki i praw politycznych znajduje się w Konwencji o Prawach Dziecka. Bezpłatność i powszechność szkolnictwa określa Konstytucja Rzeczypospolitej Polskiej. Szczegółowe przepisy dotyczące nauki i warunków rozwoju ucznia w szkole określają Ustawa o systemie oświaty (z dnia 7 września 1997 r.) i niektóre rozporządzenia Ministra Edukacji Narodowej.

3 Przytoczona lista stanowi opracowanie własne na podstawie Konwencji o Prawach Dziecka. Szerzej prawa te opisuje m.in. M. Osuch w swoim zestawieniu Karta Praw Ucznia na stronie: http:// www.maciekosuch.com/category/karta-praw-ucznia (dostęp: 30.11.2012). 
Jak już wyżej wspomniano, głównym celem omawianych w tym artykule badań było poznanie wiedzy, opinii i doświadczeń gimnazjalistów związanych z prawami ucznia. W bardziej szczegółowym sformułowaniu cele tych badań przedstawiały się następująco:

1. Zbadać wiedzę uczniów na temat przysługujących im w szkole praw.

2. Wskazać źródła wiedzy uczniów na temat ich praw.

3. Zbadać, czy, jak często i jakie prawa są (w ocenie uczniów) łamane.

4. Opisać okoliczności, w jakich łamane są prawa ucznia, oraz wskazać osoby, które to czynią.

5. Zbadać opinię uczniów na temat przyczyn łamania przysługujących im w szkole praw.

6. Porównać wiedzę na temat praw ucznia oraz opinie i doświadczenia dotyczące tych praw, gimnazjalistów z roku 2006 z wiedzą, opiniami i doświadczeniami dotyczącymi praw ucznia, gimnazjalistów z roku 2012.

W badaniach posłużono się kwestionariuszem ankiety; przeprowadzono je w 2006 i 2012 roku. Badaniami zostali objęci uczniowie z miast w województwie wielkopolskim. Kwestionariusze ankiety rozdawano w szkołach, po uprzedniej konsultacji z dyrektorami i pedagogami szkolnymi.

W badaniach wzięło udział w sumie 223 uczniów z pięciu różnych szkół, w tym 145 osób w 2006 roku i 78 osób w 2012 roku. Dane dotyczące respondentów przedstawiam w tabelach nr 1 i 2 .

Tabela 1. Charakterystyka badanej próby ze względu na płeć

\begin{tabular}{|l|r|r|c|c|}
\cline { 2 - 5 } \multicolumn{1}{c|}{} & \multicolumn{2}{c|}{2006} & \multicolumn{2}{c|}{2012} \\
\hline Płeć & D.b. & $\%$ & D.b. & $\%$ \\
\hline Chłopcy & 46 & 31,7 & 44 & 56,4 \\
\hline Dziewczęta & 99 & 68,3 & 34 & 43,6 \\
\hline Suma & 145 & 100,0 & 78 & 100,0 \\
\hline
\end{tabular}

Źródło: badania własne

Tabela 2. Charakterystyka badanej zbiorowości ze względu na wiek

\begin{tabular}{|l|r|c|c|c|}
\cline { 2 - 5 } \multicolumn{1}{c|}{} & \multicolumn{2}{c|}{2006} & \multicolumn{2}{c|}{2012} \\
\hline Wiek & D.b. & $\%$ & D.b. & $\%$ \\
\hline $13-14$ & 73 & 50,3 & 30 & 38,5 \\
\hline Suma & 72 & 49,7 & 48 & 61,5 \\
\hline
\end{tabular}

Źródło: badania własne 
Realizując pierwszy z wymienionych wyżej celów badań, chciałam ustalić, czy uczniowie wiedzą, że posiadają jakieś prawa, i czy je rozumieją.

Okazało się, że ponad połowa gimnazjalistów twierdzi, że posiada wiele lub dość dużo praw, a tylko nieco ponad $3 \%$ z nich uważa, że nie posiada żadnych praw. Pozostali stwierdzili, że mają prawa, ale jest ich niewiele. Uczniowie są zatem świadomi istnienia przepisów zapewniających im uprawnienia i wolności. Warto przy tym zauważyć, że wyniki badań dotyczące omawianej kwestii nie różnią się w grupie gimnazjalistów z 2006 i 2012 roku.

Inaczej przedstawia się kwestia rozumienia przez uczniów ich praw. Okazało się, że większość badanych deklarowała bardzo wysoki lub wysoki poziom rozumienia swoich praw ${ }^{4}$. Porównując wyniki badań z 2006 roku z tymi, które przeprowadzono w roku 2012, można zauważyć, że wzrosła liczba uczniów, którzy stwierdzają, że nie rozumieją swoich praw lub rozumieją je w małym stopniu (w 2006 roku o braku zrozumienia praw mówiło 9\% ankietowanych, a w 2012 roku już 20\%). Jest to niewątpliwie niepokojące zjawisko. Nie można jednak wykluczyć tego, że gimnazjaliści stali się bardziej refleksyjni i surowiej oceniają swój poziom rozumienia poszczególnych praw. Określenie dokładnych przyczyn tego zjawiska wymaga jednak dalszych badań.

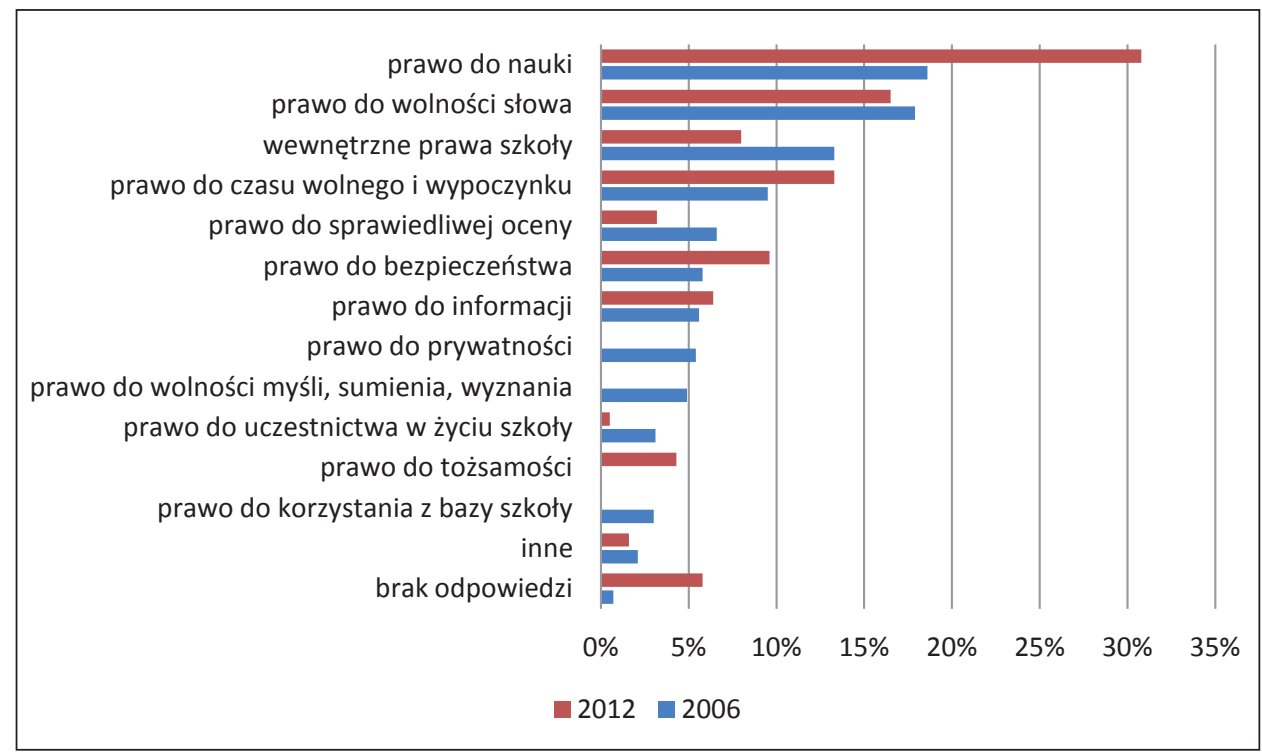

Rys. 1. Prawa, które znają uczniowie

Następnym celem, który postawiłam, było zbadanie wiedzy uczniów na temat rodzaju praw, jakie im przysługują. Prośba, którą (w ankiecie) skierowałam

\footnotetext{
4 Badałam jedynie poczucie młodzieży, dotyczące rozumienia przez nią swoich praw.
} 
do respondentów brzmiała: Wymień, jakie znasz prawa ucznia. Odpowiedzi, jakie uzyskałam, przedstawiam na rysunku nr 1 .

Jak wynika z przedstawionych na rysunku nr 1 danych, największy odsetek gimnazjalistów (zarówno z roku 2006, jak i 2012) wie o swoim prawie do nauki i wolności słowa. Znajomość pozostałych praw różnicuje gimnazjalistów z 2006 roku i 2012 roku. Współcześni gimnazjaliści lepiej niż gimnazjaliści z roku 2006 orientują się w swoim prawie do czasu wolnego i wypoczynku, prawie do bezpieczeństwa i prawie do tożsamości. Z kolei gimnazjaliści, którzy uczęszczali do gimnazjum w roku 2006 częściej (niż współcześni) wskazywali na prawo do sprawiedliwej oceny, prawo do prywatności, wolności sumienia i wyznania, godności i szacunku, uczestnictwa w życiu szkoły; znacząco większy odsetek gimnazjalistów z roku 2006 zna wewnętrzne prawa szkoły. Warte podkreślenia jest to, że żaden z gimnazjalistów z roku 2012 nie wskazał na (wymieniane przez uczniów uczęszczających do gimnazjum w 2006 roku) prawo do prywatności, wolności sumienia, wyznania, godności i szacunku i korzystania $z$ bazy szkoły.

Jak już wspomniałam, jednym z moich celów było wskazanie źródeł wiedzy na temat przysługujących uczniom praw, a więc osób i miejsc, w których dowiadują się oni o swoich prawach. Badania wykazały, że miejscem tym jest szkoła (należy podkreślić, że jej znaczenie na przestrzeni lat wzrosło, gdyż w 2006 roku wskazało ją 40\% badanych, a w 2012 roku - 55\%) i dom (w 2006 roku - 12\% wskazań, w 2012 roku - 16\%). Ankietowani wskazywali też na inne źródła wiedzy, takie jak: telewizja, Internet, prasa, książki, dzienniczek ucznia czy też Kościół, z czego największą rolę odgrywała telewizja i Internet.

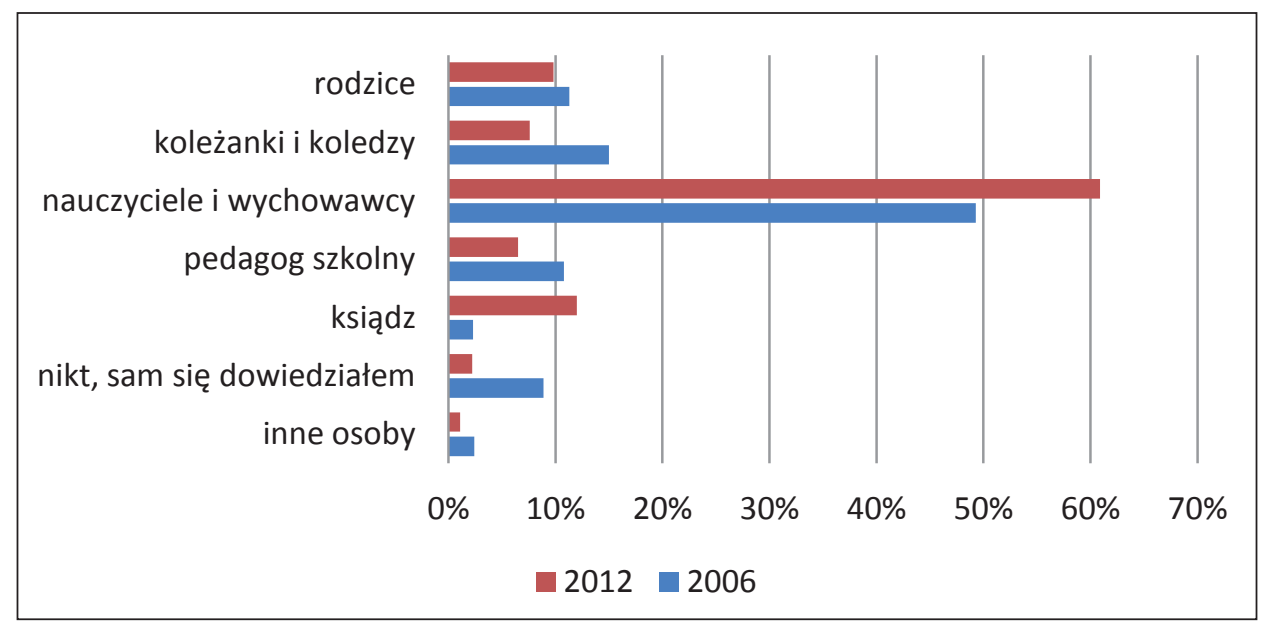

Rys. 2. Osoby, od których uczniowie dowiedzieli się o swoich prawach 
Ważne było dla mnie również to, kto informuje uczniów o ich prawach. Wykaz tych osób przedstawiam na rysunku nr 2.

Jak można zauważyć, na przestrzeni lat zwiększyło się znaczenie nauczycieli i wychowawców w kwestii przekazywania gimnazjalistom wiedzy o ich prawach, a zmniejszyła się rola pedagoga szkolnego. Taka zmiana może być efektem większego zaangażowania się nauczycieli w propagowanie idei praw ucznia w szkole. Okazuje się, że uczniowie czerpią informacje częściej od dorosłych niż od rówieśników. Świadczyć to może o tym, że zarówno w szkole, jak i w domu mówi się o prawach ucznia, a nauczyciele i rodzice są coraz bardziej świadomi roli, jaką one odgrywają.

Oprócz wiedzy i opinii gimnazjalistów na temat ich praw w szkole, przedmiotem badań uczyniłam także doświadczenia uczniów dotyczące poszanowania tych praw.

Przeprowadzone przeze mnie badania pozwoliły mi opisać okoliczności, w jakich dochodzi do łamania praw ucznia, jak również wskazać osoby, które to czynią.

Jak się okazuje, osobami, które najczęściej naruszają prawa ucznia, są nauczyciele. $\mathrm{Z}$ zadowoleniem można jednak odnotować spadek liczby wskazań na nauczycieli jako osoby łamiące prawa ucznia; w roku 2006 około 45\% uczniów wskazywało nauczycieli, podczas gdy w roku 2012 było ich niespełna 30\%. Niestety, przeciwną tendencję odnotować można w odniesieniu do pedagoga szkolnego; współcześnie aż 10\% uczniów zarzuca pedagogowi szkolnemu łamanie praw; w roku 2006 odsetek takich uczniów był znacznie mniejszy i wynosił około 3\%.

Wykaz osób, które, według badanych, naruszają ich prawa, przedstawiłam na rysunku nr 3.

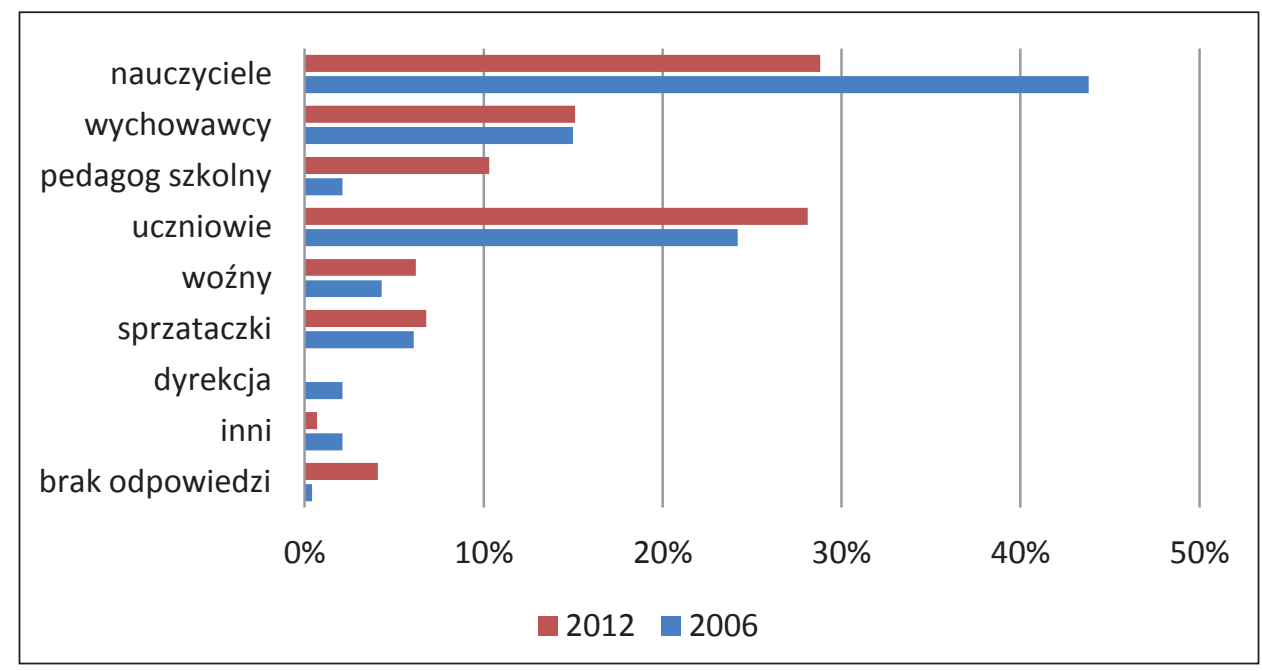

Rys. 3. Osoby naruszające prawa ucznia 
W opisie okoliczności, w jakich dochodzi do łamania praw uczniowskich, uwzględniłam rodzaj sytuacji i miejsca, w których to się dzieje, jak również miej$\mathrm{sca}^{5}$. Sytuacje, które wskazywali badani przedstawiłam w tabeli nr 3.

Tabela 3. Dziedziny życia szkolnego, w których prawa ucznia są łamane

\begin{tabular}{|c|c|c|c|c|c|c|c|c|c|c|}
\hline \multirow[b]{3}{*}{$\begin{array}{l}\text { Dziedziny życia } \\
\text { szkolnego }\end{array}$} & \multicolumn{10}{|c|}{ Częstotliwość łamania praw ucznia w poszczególnych dziedzinach życia } \\
\hline & \multicolumn{2}{|c|}{ 通 } & \multicolumn{2}{|c|}{ 通 } & \multicolumn{2}{|c|}{ 急 } & \multicolumn{2}{|c|}{ 苞 } & \multicolumn{2}{|c|}{ 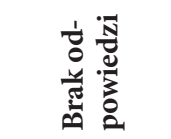 } \\
\hline & 2006 & 2012 & 2006 & 2012 & 2006 & 2012 & 2006 & 2012 & 2006 & 2012 \\
\hline $\begin{array}{l}\text { na lekcjach, } \\
\text { podczas nauki }\end{array}$ & 13,8 & 12,8 & 37,9 & 33,3 & 37,9 & 33,3 & 9,0 & 14,1 & 3,4 & 2,6 \\
\hline $\begin{array}{l}\text { podczas } \\
\text { sprawdzania } \\
\text { wiedzy }\end{array}$ & 11,0 & 9,0 & 39,3 & 34,6 & 39,3 & 33,3 & 8,3 & 16,7 & 3,4 & 3,8 \\
\hline $\begin{array}{l}\text { na przerwach, } \\
\text { podczas czasu } \\
\text { wolnego }\end{array}$ & 4,1 & 21,8 & 20,7 & 25,6 & 53,1 & 32,1 & 21,4 & 14,1 & 3,4 & 1,3 \\
\hline $\begin{array}{l}\text { podczas spotkań } \\
\text { samorządu }\end{array}$ & 0,7 & 7,7 & 3,4 & 9,0 & 35,1 & 20,5 & 51,0 & 51,3 & 6,2 & 17,9 \\
\hline $\begin{array}{l}\text { podczas } \\
\text { zajęć poza- } \\
\text { lekcyjnych }\end{array}$ & 2,1 & 9,0 & 3,4 & 17,9 & 32,4 & 38,5 & 60,7 & 28,2 & 3,4 & 2,6 \\
\hline $\begin{array}{l}\text { podczas zajęć } \\
\text { świetlicowych }\end{array}$ & 1,4 & 6,4 & 2,1 & 20,5 & 20,7 & 34,6 & 60,7 & 30,8 & 4,1 & 28,2 \\
\hline $\begin{array}{l}\text { podczas } \\
\text { wycieczek } \\
\text { klasowych }\end{array}$ & 6,9 & 12,8 & 14,5 & 30,8 & 44,8 & 33,3 & 31,7 & 14,1 & 4,8 & 3,8 \\
\hline
\end{tabular}

Odpowiedzi uczniów wskazujące na miejsce, w których łamane są ich prawa, są bardzo zróżnicowane, co może być związane z sytuacją ucznia; wobec ucznia uzyskującego wysokie wyniki w nauce nauczyciele rzadziej stosują różnego rodzaju represje. Przypuszczenie to wymagałoby jednak potwierdzenia w toku dalszych, pogłębionych badań na ten temat. Nie zmienia to faktu, że najwięcej badanych uznało, że ich prawa są łamane w trakcie lekcji.

Jak wynika $\mathrm{z}$ badań, łamanie praw może mieć miejsce na różnych przedmiotach, bo jak napisał jeden $\mathrm{z}$ respondentów: „To nie zależy od przedmiotu, tylko od nauczyciela prowadzącego" (uczeń klasy drugiej, 14 lat, badanie z roku 2006)

5 Miejscami, w których dochodzi do łamania praw ucznia, jest klasa, korytarz szkolny, boisko, szatnia, toaleta i teren nienależący do szkoły. 
Podobną myśl formułuje uczennica klasy drugiej: „Prawa łamie się podczas lekcji, na których nauczyciel jest bardzo surowy lub nie umie utrzymać dyscypliny” (14 lat, badanie z roku 2006). Można zatem zauważyć, że według badanych rodzaj prowadzonego przedmiotu nie ma znaczenia dla przestrzegania bądź łamania praw ucznia.

Jednym z celów mojej pracy było zbadanie, w jakim stopniu i jakie prawa ucznia są łamane. Zapytałam zatem moich respondentów, czy prawa ucznia są w szkole przestrzegane. W 2006 roku nieco ponad połowa badanych (52\%) uznała, że tak, ale tylko częściowo. Jeśli uznać, że dopiero duży i bardzo duży stopień przestrzegania praw ucznia świadczy o zadowalającej sytuacji w szkole, to możemy stwierdzić, że pozytywne opinie na ten temat wyraziło około $30 \%$ badanych $(4 \%$ wskazało bardzo duży, a $28 \%$ duży stopień przestrzegania praw).

Podobne wyniki uzyskała E. Stafiej, w przeprowadzonych w 2003 roku badaniach młodzieży licealnej (Stafiej, 2003: 123). Istotne różnice można jednak zauważyć, porównując te wyniki z wynikami badań przeprowadzonych przeze mnie w 2012 roku. Liczba osób wydających pozytywne opinie na temat przestrzegania praw ucznia zmalała z 30\% (w 2006 roku) do 24\% (w 2012 roku). Liczba respondentów uznających, że ich prawa są częściowo przestrzegane, zmalała z 52\% (w 2006 roku) do 39\% (w 2012 roku). Wzrosła natomiast liczba osób negatywnie oceniających realizację praw ucznia w szkole. W 2006 roku 12\% badanych uznało, że prawa ucznia są w małym stopniu przestrzegane, a 1\% badanych uznało, że w ogóle ich prawa nie są przestrzegane, natomiast w 2012 roku aż 31\% respondentów uznało, że prawa ucznia są przestrzegane w małym stopniu, a $6 \%$ badanych uznało, że ich prawa nie są przestrzegane. Dane te pokazują tendencję wzrostową w negatywnym ocenianiu stopnia realizacji praw uczniowskich. Przyczyną takiego stanu rzeczy może być pogorszenie się sytuacji ucznia w szkołach lub/i zwiększenie się poziomu wiedzy uczniów na temat ich praw. Jak wykazały badania, gimnazjaliści są częściej informowani przez nauczycieli i rodziców o ich uprawnieniach i wolnościach, przez co prawdopodobnie są bardziej świadomi, gdy są one ograniczane.

Badając realizację praw ucznia, poprosiłam respondentów, by określili częstotliwość przestrzegania konkretnych praw. Szczegółowe dane na ten temat przedstawia tabela nr 4.

Wyniki badań pokazują, że w największym stopniu w szkołach respektuje się prawo do nauki. Jest to dość specyficzne uprawnienie, bo będące jednocześnie obowiązkiem. Nierealizowanie obowiązku szkolnego przez ucznia (małoletniego) wiąże się dla jego rodziców z określonymi sankcjami ${ }^{6}$. Również dla nauczycieli jest to bardzo ważne prawo, gdyż realizowanie go łączy się z wypełnianiem funk-

${ }^{6}$ Kiedy szkoła (wychowawca, pedagog szkolny, dyrektor) nie są w stanie wyegzekwować realizacji przez dziecko obowiązku szkolnego, sprawa kierowana jest do sądu rodzinnego, który decyduje o podjęciu kolejnych kroków w tej kwestii. 
Tabela 4. Opinie uczniów na temat praw, które są najczęściej łamane

\begin{tabular}{|c|c|c|c|c|c|c|c|c|c|c|c|c|}
\hline \multirow[b]{3}{*}{ Prawa } & \multicolumn{12}{|c|}{ Częstotliwość łamania praw ucznia } \\
\hline & \multicolumn{2}{|c|}{ 茷 } & \multicolumn{2}{|c|}{ 递 } & \multicolumn{2}{|c|}{ 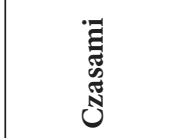 } & \multicolumn{2}{|c|}{ 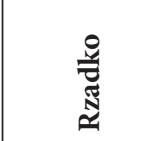 } & \multicolumn{2}{|c|}{ 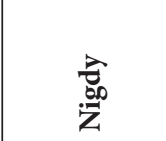 } & \multicolumn{2}{|c|}{ 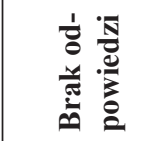 } \\
\hline & 2006 & 2012 & 2006 & 2012 & 2006 & 2012 & 2006 & 2012 & 2006 & 2012 & 2006 & 2012 \\
\hline $\begin{array}{l}\text { prawo } \\
\text { do informacji }\end{array}$ & 4,8 & 6,4 & 12,4 & 12,8 & 15,9 & 10,3 & 39,3 & 43,6 & 26,2 & 24,4 & 1,4 & 2,6 \\
\hline $\begin{array}{l}\text { prawo } \\
\text { do nauki }\end{array}$ & 2,1 & 7,7 & 5,5 & 3,8 & 6,9 & 6,4 & 16,6 & 21,8 & 68,3 & 59,0 & 0,7 & 1,3 \\
\hline $\begin{array}{l}\text { prawo do } \\
\text { wypoczynku/ } \\
\text { czasu wolnego }\end{array}$ & 19,3 & 12,8 & 21,4 & 11,5 & 22,1 & 25,6 & 20,0 & 24,4 & 17,2 & 23,1 & 0 & 2,6 \\
\hline $\begin{array}{l}\text { prawo od zrze- } \\
\text { szania się }\end{array}$ & 2,8 & 3,8 & 2,1 & 12,8 & 13,8 & 23,1 & 27,6 & 19,2 & 53,8 & 36 & 0 & 5,1 \\
\hline $\begin{array}{l}\text { prawo } \\
\text { do szacunku } \\
\text { i godności }\end{array}$ & 5,5 & 9,0 & 15,9 & 14,1 & 29,7 & 25,6 & 33,1 & 25,6 & 15,9 & 24,4 & 0 & 1,3 \\
\hline $\begin{array}{l}\text { prawo do wol- } \\
\text { ności myśli, } \\
\text { sum., wyzn. }\end{array}$ & 6,2 & 9,0 & 14,5 & 9,0 & 33,8 & 24,4 & 24,8 & 30,8 & 20,7 & 24,4 & 0 & 2,6 \\
\hline $\begin{array}{l}\text { prawo do wol- } \\
\text { ności słowa }\end{array}$ & 7,6 & 15,4 & 20,7 & 17,9 & 37,3 & 11,5 & 24,1 & 29,5 & 10,3 & 23,1 & 0 & 2,6 \\
\hline $\begin{array}{l}\text { prawo do } \\
\text { prywatności }\end{array}$ & 2,1 & 16,7 & 10,3 & 9,0 & 25,5 & 12,8 & 35,2 & 29,5 & 25,5 & 30,8 & 1,4 & 1,3 \\
\hline $\begin{array}{l}\text { prawo do bez- } \\
\text { pieczeństwa }\end{array}$ & 3,4 & 12,8 & 3,4 & 14,1 & 22,1 & 21,8 & 29 & 23,1 & 42,1 & 25,6 & 0 & 2,6 \\
\hline $\begin{array}{l}\text { prawo do } \\
\text { sprawiedliwej } \\
\text { oceny }\end{array}$ & 18,6 & 11,5 & 28,3 & 14,1 & 26,2 & 20,5 & 22,1 & 32,1 & 4,8 & 20,5 & 0 & 1,3 \\
\hline
\end{tabular}

Źródło: badania własne (z 2006 i 2012 roku)

* Tabela zawiera dane procentowe

cji dydaktycznej szkoły, która jest przez nich szczególnie ceniona (często stawiana na pierwszym miejscu, przed funkcją wychowawczą, opiekuńczą i innymi). Zauważyć można również, że wzrosła liczba gimnazjalistów dostrzegających łamanie ich prawa do bezpieczeństwa. Nie jest zatem w pełni zaspokajana w szkole jedna z podstawowych potrzeb człowieka. Można przypuszczać, że atmosfera niepokoju czy zagrożenia ma negatywny wpływ na rozwój ucznia. Pozytywne zmiany odnotowałam natomiast w przypadku prawa do zrzeszania się i prawa do informacji. Ponad połowa badanych uznała, że są one naruszane rzadko lub nigdy. 
Przeprowadzone badania miały ukazać nie tylko, jakie prawa ucznia są łamane, ale też, na czym polega ich nieprzestrzeganie. Okazało się, że wielu gimnazjalistów miało problem ze wskazaniem konkretnych zachowań świadczących o naruszaniu ich praw (w 2006 roku nie zrobiło tego 8\% badanych, a w 2012 aż 64\%). Pozostali gimnazjaliści podawali najczęściej następujące zachowania: niedopuszczanie ucznia do głosu (27\% w 2006 roku, 6\% w 2012 roku) i niesprawiedliwe traktowanie uczniów (18\% w 2006 roku i 13\% w 2012 roku). Wypowiedzi respondentów wskazywały także na ograniczanie ich wolności słowa: „Nauczyciel ma zawsze rację” (uczennica klasy trzeciej, lat 15, badanie z roku 2012), „Nie możemy mówić tego, co uważamy za słuszne, tylko to, co musimy" (uczeń klasy drugiej, lat 14, badanie z 2006 roku).

Według respondentów przejawami nieprzestrzegania ich praw są również: ograniczanie czasu wolnego (np. przedłużanie lekcji kosztem przerwy, zadawanie prac domowych na weekend), zwracanie się do ucznia bez szacunku, nierespektowanie wcześniej ustalonych zasad, nieinformowanie o ocenach czy poniżanie za wygląd zewnętrzny. Są to zachowania wskazujące na łamanie wielu praw.

Jak pokazują badania, prawa ucznia ciągle bywają łamane. Warto zatem przedstawić przyczyny takiego stanu rzeczy. Jest to złożony problem, który wymagałby analizy różnorodnych czynników wpływających na działania nauczycieli. W przedstawianych tu badaniach, skupiono się na powodach, które wskazywali sami gimnazjaliści. Wśród nich najczęściej podawane były: chęć wykorzystania przez nauczyciela przewagi nad uczniem, nieumiejętność utrzymania dyscypliny w klasie i wiek uczniów. Wypowiedzi te pokazują, że gimnazjaliści doszukują się przyczyn łamania ich praw w bezradności nauczycieli, którzy nie umiejąc nawiązać kontaktu z wychowankami oraz, nie potrafiąc skupić uwagi klasy, wykorzystują swoją przewagę nad nią (wynika ona m.in. z tego, że są dorośli, odpytują, wystawiają oceny). Jako powody łamania praw ucznia badani wskazywali również brak reakcji na to zjawisko ze strony otoczenia, a także brak kar dla osób dopuszczających się niezgodnych z prawem zachowań. Niewielki odsetek badanych uważa, że nieprzestrzeganie praw wynika z ich nieznajomości (5\% odpowiedzi w 2006 roku, $8 \%$ odpowiedzi w 2012 roku).

Jak już wspomniano wyżej, badani, jako ważną przyczynę łamania ich praw podali nieumiejętność utrzymania przez nauczyciela dyscypliny w klasie. Można zatem zastanawiać się, w jakim stopniu do łamania praw uczniowskich przez nauczycieli przyczyniają się zachowania uczniów. Aby dowiedzieć się, co sądzą na ten temat gimnazjaliści, zadałam im pytanie: czy uczniowie są winni temu, że nie są przestrzegane ich prawa w szkole? Ich zdania na ten temat były podzielone. W 2006 roku respondentów uważających, że mają wpływ na łamanie ich praw bardzo często i często, było 18\%, a tych przyjmujących przeciwne stanowisko było 38\%. Natomiast w 2012 roku respondentów wskazujących częsty i bardzo częsty 
wpływ uczniów na łamanie ich praw było tyle samo, co respondentów uważających odwrotnie (33\%). Pozostali uznali, że uczniowie tylko czasem są winni temu, że ich prawa nie są przestrzegane.

Jednym z moich zamierzeń było poznanie konkretnych zachowań uczniów, które, według nich, powodują nieprzestrzeganie ich praw. Zachowania, jakie wskazywali uczniowie, przedstawiłam w tabeli nr 5 .

Jak wynika $\mathrm{z}$ danych przedstawionych $\mathrm{w}$ tabeli $\mathrm{nr} 5$, według uczniów, do łamania praw uczniów przez nauczycieli dochodzi najczęściej wskutek takich

Tabela 5. Zachowania uczniów powodujące nieprzestrzeganie ich praw

\begin{tabular}{|c|c|c|c|c|c|c|c|c|c|c|c|c|}
\hline \multirow[b]{3}{*}{$\begin{array}{l}\text { Zachowania } \\
\text { uczniów }\end{array}$} & \multicolumn{12}{|c|}{ Częstotliwość } \\
\hline & \multicolumn{2}{|c|}{ 莍 } & \multicolumn{2}{|c|}{ 递 } & \multicolumn{2}{|c|}{ 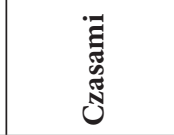 } & \multicolumn{2}{|c|}{ 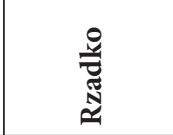 } & \multicolumn{2}{|c|}{$\frac{\vec{c}}{\mathrm{z}}$} & \multicolumn{2}{|c|}{ 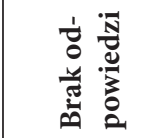 } \\
\hline & 2006 & 2012 & 2006 & 2012 & 2006 & 2012 & 2006 & 2012 & 2006 & 2012 & 2006 & 2012 \\
\hline $\begin{array}{l}\text { przeszkadzanie } \\
\text { w prowadze- } \\
\text { niu zajęć }\end{array}$ & 20,1 & 17,9 & 44,8 & 24,4 & 21,4 & 26,9 & 8,3 & 10,3 & 4,1 & 15,4 & 0 & 3,8 \\
\hline $\begin{array}{l}\text { nieudzielenie } \\
\text { odpowiedzi } \\
\text { podczas spr. } \\
\text { wiedzy }\end{array}$ & 3,4 & 7,7 & 13,1 & 12,8 & 35,9 & 24,4 & 36,6 & 32,1 & 9,7 & 16,7 & 0 & 6,4 \\
\hline $\begin{array}{l}\text { niegrzeczne } \\
\text { odnoszenie się } \\
\text { do nauczyciela }\end{array}$ & 10,3 & 25,6 & 26,2 & 15,4 & 30,3 & 24,4 & 23,4 & 11,5 & 9,0 & 19,2 & 0 & 3,8 \\
\hline $\begin{array}{l}\text { łamanie } \\
\text { praw innych } \\
\text { uczniów }\end{array}$ & 5,5 & 10,3 & 13,1 & 21,8 & 25,5 & 26,9 & 37,2 & 20,5 & 16,6 & 15,4 & 0 & 5,1 \\
\hline $\begin{array}{l}\text { niewypełnia- } \\
\text { nie obowiąz- } \\
\text { ków ucznia }\end{array}$ & 5,5 & 10,3 & 20 & 24,4 & 37,2 & 28,2 & 29,0 & 15,4 & 7,6 & 17,9 & 0 & 3,8 \\
\hline $\begin{array}{l}\text { nieprzygoto- } \\
\text { wanie się do } \\
\text { zajęć }\end{array}$ & 11,0 & 10,3 & 24,8 & 12,8 & 34,5 & 29,5 & 24,8 & 20,5 & 4,1 & 20,5 & 0 & 6,4 \\
\hline $\begin{array}{l}\text { nieupomina- } \\
\text { nie się o swoje } \\
\text { prawa }\end{array}$ & 19,3 & 10,3 & 19,3 & 15,4 & 22,8 & 24,4 & 16,6 & 19,2 & 19,3 & 25,6 & 0 & 5,1 \\
\hline inne & 1,4 & 0 & 0 & 0 & 0 & 0 & 0 & 0 & 0 & 0 & 0 & 0 \\
\hline
\end{tabular}


zachowania jak: przeszkadzanie w prowadzeniu zajęć, niegrzeczne odnoszenie się do nauczyciela, ale też niewypełnianie przez uczniów obowiązków i nieprzygotowanie się do zajęć. Można zatem przypuszczać, że prawa łamane będą wtedy, gdy nauczyciel nie radzi sobie z realizacją zadań dydaktycznych. Można się zatem domyślać, że częściej łamane będą prawa tych osób, które są nieobowiązkowe, bądź mają kłopoty w nauce. Przeczy to idei praw ucznia, bowiem uprawnienia i wolności przysługujące dziecku w szkole powinny być realizowane bezwarunkowo.

Podsumowując wyniki przeprowadzonych badań, stwierdzić można, że:

1. Szkoła jest miejscem, w którym informuje się ucznia o jego prawach. Gimnazjaliści wiedzą, że przysługują im prawa, i potrafią je wymienić. Gorzej przedstawia się rozumienie praw przez uczniów. Można zatem przypuszczać, że uczniowie są słabo przygotowani do korzystania ze swoich praw. Dorośli, przekazując uczniom wiedzę na ten temat, powinni skłonić ich do pogłębionej refleksji, tak, by prawa ucznia nie stały się wyłącznie podstawą do roszczeń gimnazjalistów wobec nauczycieli.

2. Nauczyciele coraz rzadziej dopuszczają się naruszania praw ucznia, co powinno wpłynąć na polepszenie się warunków nauczania. Rzadziej dochodzi do łamania praw ucznia w klasie, ale, niestety, częściej zdarza się to w czasie wolnym, który nie jest w żaden sposób zorganizowany. Jest to niepokojące zjawisko, gdyż czas wolny jest dla uczniów szansą na odpoczynek, regenerację sił czy samorozwój. Łamanie praw ucznia w czasie wolnym ogranicza te możliwości. Być może szkoły powinny poszerzyć kierowaną do uczniów, ofertę spędzania wolnego czasu, by uniknąć sytuacji, w których wzrasta ryzyko naruszania ich praw.

3. Wśród praw najczęściej łamanych wyróżnić możemy prawo do wolności słowa. Nauczyciele, ograniczając je, utrudniają rozwój ich autonomii. Prawdopodobnie kieruje nimi przekonanie, że w wielu sprawach, dotyczących gimnazjalistów są bardziej kompetentni, bo mają wiedzę i doświadczenie życiowe. Być może chcą chronić uczniów przed podejmowaniem błędnych decyzji, a zarazem osłaniać siebie (bo odpowiadają za uczniów, np. za ich wyniki na egzaminach końcowych). Prawdopodobnie często mają rację, ale mimo to powinni dawać młodym ludziom możliwość wypowiadania się i dyskutowania, bo to pozwala im kształtować swoje poglądy, uczy refleksyjności i daje poczucie wpływu na sprawy, które ich dotyczą. Ważne, by nauczyciele dbali o kulturę tych wypowiedzi i poziom dyskusji.

4. Za przyczyny nieprzestrzegania praw uczniowie uznają nieumiejętność utrzymania dyscypliny przez nauczyciela, ale też jego przewagę nad uczniem. Najczęściej łamane są prawa tych uczniów, którzy przeszkadzają w prowadzeniu zajęć, nie odnoszą się do nauczyciela z szacunkiem, a także tych, które nie wypełniają swoich obowiązków, takich jak na przykład przygotowanie się do lekcji. Można przypuszczać zatem, że przypadki naruszania praw dziecka w szkole są konsekwencją bezsilności nauczyciela wobec problemów wychowawczych i dydaktycznych, a to z kolei może być skutkiem niedoskonałości w kształceniu nauczycieli. 
Kładzie się w nim bowiem duży nacisk na kwalifikacje kierunkowe z danej dziedziny wiedzy, a ogranicza przygotowanie pedagogiczne i dydaktyczne.

Przedstawione w tym artykule wyniki badań należy traktować z ostrożnością; nie można bowiem zapominać, że badania zostały przeprowadzone tylko w szkołach miejskich i tylko w Wielkopolsce, co nie pozwala na generalizację uzyskanych wyników. Mogą one stać się natomiast impulsem dla bardziej pogłębionych i poszerzonych badań nad omawianymi w tym artykule kwestiami.

\section{Literatura}

Osuch M. (2006). Podstawy prawa oświatowego. [W:] Pedagogika: pedagogika wobec edukacji, polityki oświatowej i badań naukowych. Red. B. Śliwerski. Gdańsk

Partyka M. (1996). Prawa dziecka w szkole. [W:] Zanim w szkole będzie źle. Red. K. Ostrowska, J. Tatarowicz. Warszawa

Stafiej E. (2003). Prawa ucznia w opiniach uczniów liceów ogólnokształcacych. [W:] Prawa dziecka. Teoria i praktyka. Red. E. Markowska-Gos, H. Sommer, W. Walc. Rzeszów

Śliwerski B. (2012). Prawa dziecka w polskim systemie oświaty. Perspektywa pedagogiczna. [W:]. Prawa dziecka. Konteksty prawne i pedagogiczne. Red. M. Andrzejewski. Poznań

\section{Student's Rights: Knowledge, Views and Experiences of Gymnasium Students. A Research Report}

\section{Summary}

This paper is a report on research into students' rights. It is divided into few main sections. Firstly, issues such as the significance of school in the life of children and the rights of students in the process of education are presented. Secondly, the report involves information on scope and organization of research being conducted as well as main aims and objectives thereof. Finally, the results of the study and its conclusions are included.

This discussion begins with introducing school as an institution which main aim is to prepare new generations to be the part of society. At school students interact with different people and they learn how to follow certain rules and regulations. It is an institution which provides students with variety of skills regarded as essential in the adult life (e.g.: being familiarized with their rights and being able to make use of them). It is also noteworthy that legal documents such as the Convention on the Rights of the Children and the regulations of (Polish) educational system can be considered as a source of the students' rights. Presented analysis is based on the list of the students' rights among which one can find: the right to seek, receive and impart information, the right to education, the right to leisure and recreation, the right to freedom of association, the right to respect and being fairly treated, the right to freedom of thought, conscience and religion, the right to speak freely, the right to privacy, the right to protection and finally the right to be judged fairly. 
Main aim of the research discussed in this article was to gather information on the knowledge, opinion and experience of secondary students concerning their rights. The research, whose participants were lower-secondary students from the towns and cities of Wielkopolska province (223 people from five different schools), was conducted twice: in 2006 and 2012. In order to collect crucial data a questionnaire form has been used. As far as the aims of the research are concerned, there were six specific ones:

To test students' knowledge regarding their rights at school.

To indicate the source of this knowledge.

To investigate if, how often and which rights are not respected (according to students).

To describe the situations in which the students' rights are broken and to point out those who are responsible for it.

To examine students' opinion on the reasons why these rights are not respected.

To compare the results of the 2006 research with the one conducted in 2012.

In the first part of the research, students' awareness of their rights has been examined. Both research proved that students are aware of some of the rights they have at school. Only $3 \%$ of the respondents felt they have no rights. However, the results of the present study also show that students do not understand their rights as the number of those who claim not to understand or only partly understand their rights has increased (9\% in 2006 compared to $20 \%$ in 2012). Undoubtedly, this tendency is alarming.

The results from 2006 and 2012 study demonstrate that most of the students were aware of their right to education and the right of free speech. Other rights such as the right to leisure and recreation, the right to protection, the right to identity or the right to fair judgment were mentioned less frequently and with different frequency within years. The students who were respondents in 2012 study, unlike their predecessor from 2006, did not mention the right to privacy, the right to freedom of thought, conscience and religion or the right to dignity and respect. The study also revealed that young people learn about their rights and freedom mainly at school (from their teachers and class tutors) but also at their family house.

The experiences of lower- secondary students regarding realization of their rights have been also analyzed. The study revealed that $30 \%$ of respondents are satisfied with how their rights have been realized. Additionally, the research allowed to describe the circumstances in which the rights are not respected and to indicate who is responsible for breaching those rights. Research shows that the people who most frequently breach the students' rights are teachers, although the number of those teachers has fallen from 45\% in 2006 to only $30 \%$ in 2012 .The rights of students are not respected usually during lessons. However, it does not depend on the subject and type of lesson

The aim of this article was also to show students' opinion on the frequency of breaking their rights. Each right is being breached to a smaller or larger extend. However, the right to education has been indicated less frequently which proves that the teachers are focused on the didactic role of school. The students have also noticed that while the right to freedom of association and the right to seek, receive and impart information are obeyed, the right to protection and the right to free speech are neglected. According to students, young people at schools are not allowed to get to speak or to share their point of view.

Certainly the causes of breaking the students' rights would require further profound analysis as the factors which influence the ways teachers react may differ. However, this article shows mainly the causes which were named by lower-secondary students. It has been found that teachers' advantage over their students and teachers' inability to maintain discipline in the classroom are the most important reasons of the rights of students being not respected. Moreover, it has 
been stated that students complain about the indifference of people around them who do not react whenever their rights are broken. Only few percent of respondents claimed that this situation was caused due to lack of knowledge of the students' rights.

The results of the research show that students have different opinion on the influence of their own behavior on the cases of disrespecting their rights. Those who realized that such connection may exist, admitted that their rights are ignored when they misbehave during the lesson, are impolite or rude towards the teacher or when they neglect their school duties. That is why it can be assumed that the reason for students' rights being not respected may be related to students' behavior.

To sum up, students are aware of the rights they are entitled to but they do not understand them. This can lead to situations in which students improperly interpret their own rights. In the light of those findings, it appears clear that informing students about their rights is not sufficient as it is also necessary to teach students how to claim their rights. Furthermore, students noticed many cases in which their freedom of speech was ignored. Teachers should let their students speak and discuss problems more openly which would help students to share their opinions and to solve various problems systematically. Using proper language standards in these discussions should be also taken into consideration. It points out how significant are educational and didactic qualifications of the teachers responsible for introducing young generation to be the part of society. 
